\title{
OTTO WILHELM MASING VALGUSTUSLIKU LASTE- JA NOORTEKIRJANIKUNA
}

\author{
AVE MATTHEUS
}

$\mathrm{E}$ esti laste- ja koolikirjanduse ajaloos ei ole siinse uurimuse kangelase Otto Wilhelm Masingu (1763-1832) teosed sugugi tundmatud. Kõrgelt hinnatakse tema esimese aabits-lugemiku „ABD ehk Luggemise-Ramat Lastele, kes tahawad lugema õppida” (1795, edaspidi „ABD ehk LuggemiseRamat Lastele”) ilmalikke jutustusi (Järv 1989: 20-21; Laul 1989: 289-290; Krusten 1995: 35), esiletõstmist on leidnud ka mõningad teised kooliraamatud ja rahvavalgustuslikud tööd (Vinkel 1966: 100-146; Andresen 2002: 247248), kuid puuduvad süvendatud käsitlused Masingu loomingu sellest osast, mis on mõeldud lastele ja noortele.

Masing ei kirjutanud noorele lugejale raamatuid vaba aja veetmiseks, n-ö meelelahutuslikuks lugemiseks, tänapäevases mõttes olid kõik tema vastavad teosed pedagoogilise alatooniga ehk mõeldud õpperaamatutena kasutamiseks kas kodus või koolis. Teoste sihtgrupi vanus varieerus vastavalt žanrile, kuid oli ka topeltadresseeritud tekste. Lugema õppimise raamatud olid mõeldud arvatavasti kuni 12-aastastele lastele, kelle kohta kehtis kindralkuberner Browne'i koolipatent 1765. aastast (vt Laul 1989: 132, 141), ülejäänud neile, kes juba lugeda oskasid. Et täiskasvanuks saamise iga tähistas XVIII sajandi lõpus ja XIX sajandi alguses 17. eluaasta ületamine (vt Laul 1989: 275), võib öelda, et need tekstid olid suunatud kas lastele, noortele või noortele täiskasvanutele.

Laias laastus jagunevad Masingu laste- ja noortetekstid kaheks, ilmalikeks ja vaimulikeks, kuigi pastori ja kõrge kirikutegelasena olid kõik ta tööd kristlikest ideedest läbi põimunud. Ilmalike tekstide hulka võib arvata $8 \mathrm{nn}$ musta pedagoogika valda kuuluvat jutustust ja kombeõpetuse osa juba mainitud 1795. aasta aabits-lugemikust, samuti ajalehetekstid ning loodusteaduslikke ja antropoloogilisi lugemispalu sisaldava jutukogu „Pühhapäwa Wahheluggemissed” (1818). See aimekirjanduslik teos ei ole otseselt suunatud noorele publikule, kuid Masingu kirjavahetus Johann Heinrich Rosenplänteriga (Masing 1995: 293; 1996a: 43; 1996b: 185)ํㅣ ja lugejate kirjad (vt Beiträge 1823, 16: 65-88) annavad teada, et lapsed lugesid (või kuulasid) raamatut hea meelega, ja et see oli vähemalt Saaremaa kihelkonnakoolides kasutusel ka kooliõpikuna. Et teose kuuluvus laste- ja noortekirjandusse on vaieldav ja Aarne Vinkel (1966: 116-120) on sellest juba andnud põhjaliku ülevaate, siis ma seda alljärgnevalt lähemalt ei vaatle. Küll aga peatun Masingu koostatud ja väljaantud Marahwa Näddala-Lehel (1821-1823, 1825), mille ilukirjanduslikud lugemispalad - paraboolid, näidislood, (värss)mõistatused jms - olid mõeldud väga laiale lugejaskonnale alates lastest ja noortest kuni täiskasvanuteni.

1 Masingu kirjavahetusele viidates osutan leheküljenumbriga (enamasti saksakeelsele) originaalile, tsitaatide puhul kasutan Leo Anveldi tõlget, mis on toodud iga kirja järel. 
Kristlikku suunda Masingu laste- ja noorteloomingus esindavad ennekõike kaks mahukat usuõpetusraamatut: „Wanna-seädusse-aja sündinud asjad, mis Wannast-Testamendist kokkokirjutand ja nore rahwa õppetusseks trükki pannud Otto Willem Masing" (1819, edaspidi Vana Testamendi (VT) lood) ja „Wiiskümmend kaks Luggemist Uest-Testamendist wäljawallitsetud, kuhhu küssimisi, mis mõtlemist tahtvad, häid õppetusi, ja pühha kirja salmisid jurepandud, mis Otto Willem Masing, nore rahwa ja kolilaste heaks wäljaandnud" (1824, edaspidi Uue Testamendi (UT) lood). Usuõpetusraamatutega kuulub kokku „Täieline Ristiusso õppetus mis targema rahwa ja koolmeistrite kassuks wäljaandnud Otto Willem Masing” (1825, edaspidi "Täieline Ristiusso õppetus”). Kuigi pealkirja järgi võiks arvata, et see on õpetajaraamat, mida ta kahtlemata ongi, rõhutab Masing UT lugude lõppsõnas, et ristiusu õpetust võiks lugeda paralleelselt piiblilugudega, sest need täiendavad teineteist (Masing 1824: 238). Seega on ka „Täieline Ristiusso õppetus” mõeldud nooremale rahvale lugemiseks ja kuulub laste- ja noortekirjandusuurimuse huviorbiiti.

Masingu religioosse sisuga teoste hulka kuuluvad osaliselt ka aabitsad. 1795. aastal ilmunud „ABD ehk Luggemise-Ramat Lastele” sisaldab ilmalike tekstide kõrval katekismuseosi ja palveid; „Täieline ABD-Ramat, kust makele luggemist õiete õppida” (1823b, edaspidi „Täieline ABD-Ramat”) pakub lugemiseks pühakirjasalme, väikest katekismust ja üht palvet, mistõttu võib seda teost pidada aabits-katekismuseks. Õppematerjal „Luggemisse lehhed mis Otto Willem Masing wäljaandnud” (1821a) kordab „Täielist ABD-Ramatut", kuigi selles puuduvad katekismus ja palve ning lugemiseks on vaid pühakirjaõpetused. Seetõttu on seda trükist raske pidada sisuliselt või metoodiliselt iseseisvaks õpperaamatuks. „Luggemisse lehtede” juurde käiv metoodiline abivahend „Ôppetus kuida neid luggemise lehti kassuga prukida, mis Otto Willem Masing wäljaandnud" (1821b) on klassikaline opetajaraamat ja pakub pedagoogilist, mitte kirjandusloolist huvi. Järgneva vaatluse alt jääb samuti välja Masingu matemaatikaõpik „Arwamise-ramat. 1 Tük mis Otto Willem Masing koolmeistrite ja kolilaste kassuks wäljaandnud” (1823a), mis ei sisalda ilu- või aimekirjanduslikku materjali.

\section{Religioonipedagoogilised tööd}

Masingu laste- ja noortekirjanduslikest töödest moodustavad mahukama, žanriliselt mitmekesisema ja vähem uuritud osa vaimulikud tekstid, mistõttu alustan nendest. Kuna religioosse lastekirjanduse uurimise traditsioon Eestis veel puudub, kujutavad alljärgnevad arutlused alles esimesi samme sellel teel. Toeks on mul sealjuures teiste maade kogemus (vt Reents 1984; 1991; Bottigheimer 1996; Adam, Lachmann 1999; Adam, Lachmann, Schindler 2003).

\section{Religioosne ainestik kooliõpikutes}

Kuigi Masingu esimene lasteraamat, koduõppeks mõeldud „ABD ehk Luggemise-Ramat" on alapealkirja järgi suunatud lastele, kes tahavad lugema õppida, sisaldab eessõnas oma aja kohta eesrindlikku lugemaõpetamise metoodi- 
kat ja esmakordselt eesti keeles kirjavahemärkide seletusi, on tegu pigem lugemiku kui aabitsaga, sest tähestiku ja veerimisharjutuste osa on selles väga napp (kolm lehekülge). Meie kultuurilugu hindabki teost peamiselt selles sisalduvate ilmalike lugemispalade tõttu, religioossed tekstid on jäänud valdavalt tähelepanuta, kuigi rõhutatakse, et need on varasemate aabitsatega võrreldes antud kokkusurutumalt (Järv 1989: 20). Tõepoolest, Masingu aabits-lugemikus puudub usutunnistus, mis oli toonaste aabitsate lahutamatu osa, kümne käsu ja meieisapalve kõrval on toodud mõned lühikesed palved, mida laps saab lausuda hommikul, õhtul, söögi eest tänades või muudel elupuhkudel.

Lastepalved ehk laste pöördumised jumala ja/või Kristuse poole on nii religioosse kasvatuse kui ka religioosse lastekirjanduse oluline osa. Teemakohases uurimuses eristatakse ühelt poolt selliseid palveid, mida vanemad loevad lastele või koos nendega, ja teiselt poolt selliseid, mida lapsed sõnastavad ja loevad ise (Bichler 2001: 2). Masingu lastepalved vastavad pigem esimesele tüübile, sest neis leidub vähe lastepärase mõttemaailma ja eluviisi peegeldusi. Lastepalveteks lubab neid siiski pidada tekstide lühidus, keele lihtsus, seotus lapse päevarežiimiga ja ilmumiskoht. Varasematele sajanditele iseloomulikult on Masingu lastepalved värsivormis. Kohati päris heade rütmi- ja riimiskeemide kõrval (nt „Hommiko-Laul”) leidub ka kohmakust ja keeleväänamist (nt „Sööma palwe”).

Masingu teine aabits, 1823. aastal ilmunud „Täieline ABD-Ramat” on juba rohkem lugemaõppimise raamatu moodi. See 40-leheküljeline raamatuke sisaldab tähestikku, silbitamis- ja veerimisharjutusi, õpetussõnu-pühakirjasalme, katekismuse osi ja üht palvet lugemiseks. Teises pooles on antud algteadmisi numbrite ja kirjavahemärkide kohta, toodud piiblitegelaste nimekujud saksa-eesti võrdluses ning raamatu lõpetab rohkem õpetajatele kui õpilastele suunatud peatükk, mis sisaldab lühikesi selgitusi selle kohta, mis on veerimine, millised lühendid on käibel, kuidas kasutada õ-tähte ning millistest osadest koosneb UT.

Kirjandusloolises mõttes on kõige huvipakkuvamad õpetussõnad, mis on valdavalt pärit UT-st ja Lauluraamatust. Suurem osa neist räägib jumala võimsusest ja tarkusest ning manitseb lugejaid kuulekusele ja allaheitlikkusele, kuid on ka valgustusajastu lastekirjandusele tüüpilist moraali- ja kombeõpetust (nt joomise, varastamise, valetamise, vägisõnade pruukimise keeld jms). Aabits-katekismuse ainsas palves, mis algab sõnadega „Ma ollen weike lapsoke” (Masing 1823b: 26), võib lapslugeja end paremini ära tunda, sest selles rõhutatakse jumala ülistamise kõrval ka vajadust austada oma vanemaid, kuid üldiselt ei ole teos mõeldud (ainult) lastele, vaid võimalikult laiale kasutajateringile.

Võrreldes 1795. aasta aabits-lugemikuga, mis on žanriliselt mitmekesine ja maailmavaateliselt avatud, on „Täielise ABD-Ramatu” tekstivalik konservatiivne ja piiratud. Võib arvata, et Masingu rangemaks muutunud religioossete hoiakute taga oli võitlus hernhuutlastega, mis teravnes eriti 1810 . aastate lõpus ja 1820. aastate alguses (vt Põldmäe 2011: 425-470). Adressaatide ringi laiendamine räägibki tõenäoliselt sellest, et Masingu arvates ei olnud kristlikku elementaarõpetust vaja anda mitte ainult lastele, vaid ka noortele (täiskasvanutele), kes kippusid libisema vennastekoguduse jutlustajate mõjuvõimu alla. 


\section{Piiblilood}

Kõige huvitavamad Masingu religioossest laste- ja noortekirjandusest on kahtlemata piibli ümberjutustused, mis on koondatud kahte väljaandesse VT ja UT lood -, kuid kavandatud ühtsena. Uut valgust nii Masingu kirjanduslikule tegevusele kui ka XIX sajandi alguse eesti kultuuriloole tervikuna heidab asjaolu, et neile lugudele on eeskujuks olnud saksa pedagoogi, koolikirjaniku ja varavalgustaja Johann Hübneri (1668-1731) traditsioone loov teos „Zweymal zwey und funffzig Auserlesene Biblische Historien Aus dem Alten und Neuen Testamente” (1714, „Kaks korda viiskümmend kaks valitud lugu Vanast ja Uuest Testamendist") (vt Masing 1996a: 52, 244), mis kujundas Saksamaal piibliõpetuse suundi kogu XVIII sajandi vältel, arvukate tõlgete ja muganduste kaudu ka mujal Euroopas ning isegi Ameerikas (Reents 1984: 269-275). ${ }^{2}$ Et piiblilood on religioosse laste- ja noortekirjanduse üks iseloomulikumaid vorme, kuid Eestis veel täiesti läbiuurimata teema, analüüsin põhjalikumalt nii lugude valikupõhimõtteid kui ka nende keelelis-stiililise vormimise eripärasid. Vaatlen Masingu ja Hübneri teoseid võrdlevalt, et selgitada välja Masingu tööle iseloomulikud tunnused.

Juba tekstide pealiskaudsel vaatamisel näeme, et Masingu raamatute peatükkide arv kaldub kohati Hübneri omast kõrvale. VT lugude puhul on ta piirdunud 39 peatükiga Hübneri 52 asemel, UT lugude puhul on järginud Hübneri eeskuju, sest selles on tal samuti 52 lugu. Christine Reents, kes on põhjalikult uurinud Hübneri piiblilugusid, on toonud välja, et 52 viitab nädalate arvule aastas, andes mõista, et igal nädalal võiks raamatust lugeda ühe loo. Reentsi arvates on see reformatsioonieelse kiriku perikoobikorralduse pärand, mille Luther üle võttis ja mida kasutati päris palju hingekosutus- ehk harduskirjanduses (Reents 1991: 235-236). Masingu puhul võib oletada, et 39 peatükki tema VT lugude puhul viitab protestantide VT 39 raamatule. Samal ajal ei ole ta pakkunud sissevaateid igasse raamatusse, vaid teinud neist oma valiku. VT lugude esimeses osas on ta üldjoontes järginud Hübneri mustrit, teises pooles käinud oma rada. UT lugude valikus on kõrvalekalded Hübnerist minimaalsed.

Nagu Hübneri nii on ka Masingu piiblilugude tekstivaliku esimene tunnusjoon lugude kronoloogiline ja loogilis-põhjuslik järgnevus. Masingu VT lugudes on esindatud kõik VT olulisemad sündmused: kanooniline loomislugu ja Iisraeli rahva esiisade lugu (1Ms), mis hõlmab umbes poole raamatust. Seejärel tuleb kaheksas peatükis juttu Iisraeli rahva orjapõlvest Egiptuses, põgenemisest kodumaale ja lepingust jumalaga Siinai mäel ( $2 \mathrm{Ms}-5 \mathrm{Ms}$ ) ning viimases kolmeteistkümnes peatükis on teemaks elamaasumine tõotatud maale ja rahva koondamine kuningate valitsemise alla (Kuningate raamat ja Ajaraamat). Prohvetite raamatute sisust räägib ta ühes väga ülevaatlikus peatükis „Prohvetid” ja VT apokrüüfidest refereerib kaht Makkabite raamatut.

Kõige suuremad erinevused Masingu ja Hübneri VT lugude vahel ilmnevad nn kuningate ajastu käsitlemisel, sest Hübner esitab rohkesti kaasahaa-

${ }^{2}$ Hübneri piiblilugude tõlkemugandused on perspektiivikas uurimisteema, sest neid on eesti keelde vahendatud rohkem kui üks kord. Esmakordselt jõudsid need meieni „Eestima Rahwa Kalendri, ehk Täht-Ramatu" (Köhleri trükikoda) veergudel 1720. aastal, kus ilmusid korduvalt kuni 1770. aastani (Annus 2000: 14). Masinguga enam-vähem samal ajal vahendas Hübnerit lastele ka pietistlik kirjamees Carl Matthias Henning (1821). 
ravaid näidislugusid erinevate valitsejate käekäigust ja teeb sageli juttu silmapaistvatest naistest (Ester, Juudit, Susanna), kuid Masingul nii selget suunitlust märgata ei ole ja naistegelasi ta peaaegu väldib.

UT lugudes on nii Hübneril kui ka Masingul valiku aluseks Jeesuse elu, mis algab peaingel Gaabrieli kuulutusega Ristija Johannese sündimisest ja lõpeb Jeesuse taevaminemise ning Pauluse uskupöördumisega. Sinna vahele jääb terve rida peatükke, mis räägivad Jeesuse imetegudest või pakuvad mõistujutte usu leidmise, kinnitamise ja praktiseerimise kohta. Mõnes peatükis kaldub Masing Hübnerist küll kõrvale, kuid suures plaanis järgib ta siiski oma saksa alusteksti ja võib arvata, et kõrvalekallete põhjuseks ei ole niivõrd teoloogilised kaalutlused, kuivõrd piibliteksti eesti lugejale vastuvõetavaks mugandamine. Masing on tekstide valikul ühelt poolt arvestanud lugeja geograafilis-klimaatilisi tingimusi (nt on ta loobunud viljatu viigipuu loost 21Mt: 18-22), teiselt poolt on ta rohkem tähelepanu pööranud lugudele, mis räägivad võitlusest usulise vastastega (vrd võitlus hernhuutlastega). Kolmandaks on tema valikutes märgata kodanliku (seksuaal)moraali rõhutamist, millest tuleb allpool põhjalikumalt juttu.

Kuigi Masing esitab oma teostes näidislugusid vähem kui Hübner, võimaldavad põhjalikumalt käsitletud Joosepi lugu ja Jeesus kui suur eeskuju rääkida näidislugude esitamisest kui tema teisest tekstivaliku põhimõttest. Näidislood tekstivaliku alusena on juba antiigist ja keskajast saadik levinud võte, mis leidis laialt kasutust nii Lutheri religioonipedagoogilistes töödes (Reents 1991: 236) kui ka paljudes hilisemates lastepiiblites või piiblimugandustes. Näidislugude esitamisele kui ühele teose põhijoonele vihjab Masing juba oma VT lugude eessõnas, kus ta annab juhtnööre selle kohta, kuidas raamatus sisalduvaid tekste pruukida: nimelt mõistlikult ja loetu üle reflekteerides. See tähendab õppimist toodud näidetest: jumalakartlikke ja vagasid inimesi ootab õnn ja rahulolu, jumalakartmatud ja õelad aga paisatakse viletsuse ja vaesuse sisse (Masing 1819: Eestkõne).

\section{Perekonnaelustseenid ja vägivald piiblilugudes}

Lutheri mõjudega on Reentsi (1991: 239) järgi ka hilisemate autorite tendents esitada piibli ümberjutustustes perekonnaelustseene, et muuta piibel kodanlikule ühiskonnale vastuvõetavaks ja piibli tegelased kodanlikule lugejale sarnasemaks. Kuigi eestikeelse raamatu lugejaskonna moodustasid XIX sajandi alguses veel suurperedes elavad talupojad, propageeris Masing oma teostes Hübneri eeskujul ka siinmail juba kodanliku tuumikpere ideaali, mida võib pidada tema kolmandaks tekstivaliku põhimõtteks. Pereelustseenide uurimine võimaldab omakorda vaadelda mitmeid tekstivaliku juures olulisi küsimusi, nagu vanemate ja laste, meeste ja naiste suhted või seksuaalsuse ja vägivalla kujutamine.

Vanemate ja laste suhteid käsitleb Masing palju: Iisaku ohverdamise lugu (VT lood ptk 9), Joosepi ja tema vendade suhted (VT lood ptk-d 10-19), Taaveti ülekäte läinud poja lugu (VT lood ptk 28) ning muidugi Jeesuse sünni- ja lapsepõlvelood (UT lood ptk 6, 10 jt). Kõigis neis juttudes on vanemate ja laste, peamiselt poegade, vahelist läbikäimist kujutatud küll üldjoontes sõbrali$\mathrm{ku}$ ja lugupidavana, kuid samas hoiatatakse vanemaid laste liigse hellitami- 
se eest ning manitsetakse neid lapsi võrdselt kohtlema, lastele aga tuletatakse meelde esivanemate austamise vajadust. Seda tendentsi illustreerib hästi Absalomi lugu: „Tawet oli teda [Absalomi - A. M.] maast maddalast liastegi armastanud ja hellitanud, selle läbbi olli temma üllemelelisseks saanud, ja südame polest hukka läinud" (Masing 1819: 55). Tagajärjeks oli ülekäte läinud poja vastuhakk elatanud isale, mis lõppes poja jaoks traagiliselt.

Kuidas kujutab Masing mehe ja naise suhteid ning seksuaalsust, mis VT kohati vägagi vabameelsete seksuaalelunäidete taustal valmistab arvatavasti kõigile adapteerijatele peavalu? Nagu juba öeldud, teeb Masing oma VT lugudes naistest tunduvalt vähem juttu kui Hübner. Näiteks mainib ta VT lugude peatükkide pealkirjades nimeliselt 12 meest, kuid naistest suudavad anonüümsusest välja murda vaid Eeva ja Saara, sedagi oma meeste kõrval (ptk 2 „Adamad luuakse mullast ja Ewad temma küljeluust”; ptk 9 „Abram ja Sara”). UT lugude pealkirjades figureerib kolm korda Jeesuse ema Maarja, mainitakse ka Johannese ema Eliisabeti ning naisi, kes Jeesuse imetegusid kogevad (Samaaria naine, Jairuse tütar, Kaananimaa naise tütar, Laatsaruse õed Marta ja Maria), kuid enamik naisi jääb anonüümseks. Väga tüüpiline Masingu piiblilugudele on selline tekstilõik: „Abramil olli poeg Isak; Isakil olli kaks poega Esaw ja Jakop, agga selle viimsele oli Jummal kaksteistkümmend poega andnud; kelle seast norem nimmega Josep olli. Sedda wannemad ennam armastasid, kui teisi, sest et temma nende wanna ea sees olli sündinud" (Masing 1819: 15). Mitte sõnagi naistest, kellega neil esiisadel pojad olid, või emadest, kes neid poegi ilmale kandsid. Muidugi ei ole mõtet Masingu tekste analüüsida tänaste feministlike mõõdupuudega, sest aeg, mil ta elas, oli patriarhaalne. Küll aga aitab sootundlik pilk mõista, kuidas piiblit ümber jutustades konstrueeriti ja taastoodeti traditsioonilist soosüsteemi, samuti näha, et kodanlikke moraaliarusaamu propageeriv Masing oli sooküsimuses tegelikult konservatiivsem kui Hübner.

Piibli(lugude) sootundlikud analüüsid on nimelt kindlaks teinud, et vabameelseid seksuaalsuhteid, mida veel XVI ja XVII sajandi saksa- ja ingliskeelsetes lastepiiblites esitati ilma igasuguse valehäbi ja liialdatud kombekuseta (Bottigheimer 1991: 26, viidatud Rosenberger 1997: 46 järgi), hakati alates XVIII sajandi keskpaigast allutama rangemale moraalsele ja pedagoogilisele tsensuurile. Kui XVII-XVIII sajandi vahetusel tegutsenud Hübneri piiblilugudes võib veel leida mitmeid episoode, kus on juttu mitmenaisepidamisest (Jaakobi naised Raahel ja Lea) või naise ähvardavast seksuaalsusest (Simson ja Delila, Taavet ja Batseba, tantsiv Salome jt) - naise vägistamise (Taaveti tütar Taamar) ja intsesti (Lot ja ta tütred) juhtumid on tema raamatust siiski välja jäänud -, võib Masingut pidada tunduvalt konservatiivsemaks. Kui Masing naisest räägib, siis ainult kui emast või abikaasast, ja nii saab kinnitust oletus, et nende Hübneri skandaalide all, mis rahvast šokeerivat ja mille ta oma piiblilugudest soovivat välja jätta, nagu ta Rosenplänterile kirjutas (vt Masing 1996a: 244), pidas ta silmas seksuaalsuse kujutamist.

Seoses seksuaalsuse kujutamisega tõstatus juba vägivalla teema, mis hõlmab piiblis tunduvalt enam aspekte kui vägivald naiste vastu või üldisemalt inimestevaheline vägivald. Piibli lastele ja noortele adapteerimisel kerkib alati üles küsimus jumala vägivaldsest loomusest. Põhimõtteliselt eristavadki (laste)piibli ja piiblilugude uurijad vägivalda, mis lähtub jumalast (nt jumala käsu vastu eksinute karm karistamine), ja vägivalda, mille põhjustavad ini- 
mesed ise, alustades jumala käsu eiramisest paradiisis kuni oma vihavaenlaste tapmiseni.

Võiks arvata, et kui Masing on seksuaalsuse kujutamisel väga kõlbeline, siis on ta seda ka vägivalla suhtes, kuid paraku see nii ei ole. Tema VT ja UT lugudest leiab vägivallastseene suhteliselt palju ja tunduvalt rohkem kui Hübneril. Kaini ja Aabeli, Iisaki ohverdamise, Joosepi ja tema alatute vendade kanooniliste lugude kõrval räägib Masing oma VT lugudes põhjalikult ka juuda ja iisraeli hõimude omavahelisest võitlusest, Jeruusalemma hävitamisest kaldealaste poolt, sellest, kuidas Nebukadnetsar juute vangipõlves pidas jne. Eriti suure jõhkruse poolest torkab silma lugu seitsmest vennast ja nende emast, keda süürlased nende usu pärast piinavad ja lõpuks tapavad, kusjuures selles tehakse juttu ka mitmesugustest piinamisviisidest (ptk 36). Inimestevaheliste tülide ja arveteklaarimiste, sõdade ja hävitustööde rohke kujutamine VT lugude viimastes peatükkides on ka põhjus, miks pean seda Masingu teksti vähem õnnestunuks kui Hübneri oma. Vägivallastseenide väljaarendusi võib leida ka Masingu UT lugudes (nt juutide viha Jeesuse vastu, Stefanose kividega surnuks loopimine jms), kuid need ei torka üldpildis häirivalt silma. Võib-olla on rohke vägivalla esitamine seotud Masingu sooviga pakkuda näiteid kangelastegudest oma usu kaitsmisel, võib-olla pidas ta eesti maarahvast jämedakoeliseks, kellega tulebki just sellisel viisil rääkida, kuid minu meelest on sellised jutud noorele lugejale mõeldud teoses igal ajal ja igas kultuuris küsitava väärtusega ning mõjuvad pigem vägivalla ja jõhkruse ülistamise kui selle eest hoiatamisena.

\section{Jumala kujutamine piiblilugudes}

Piibli adapteerimise üks keerulisemaid küsimusi on VT jumala türanlik ja brutaalne loomus. Eespool sõnastatud mulje, et Masingu piiblimuganduses domineerib inimestevaheline vägivald, ei ole intuitiivne, vaid seotud sellega, et jumal tõepoolest ei ole tema lugudes hirmutavalt vägivaldne, vastupidi, teda on kujutatud suuremeelse, armuliku, hoolitseva ja isegi heana (vt Masing 1819: 7, 9, 20, 34, 44, 49, 53 jne). Ameerika kirjandusteadlase ja (laste)piibliuurija Ruth B. Bottigheimeri sõnul on selline muutus, kus karmist ja karistavast jumalast saab heatahtlik, tark ja isalik kaitsja, toimunud Euroopa rahvaste lastepiibli ja piiblilugude väljaannetes XVIII sajandi vältel ja olnud tingitud nii pedagoogilistest kaalutlustest (süütut last tuleb kurjast eemal hoida) kui ka konfessionaalsetest arengutest, millised mõningatele erinevustele vaatamata andsid lõpuks siiski sarnase, kuigi paradoksaalse tulemuse - jumala muutumatu loomuse muutmise piiblimugandustes (Bottigheimer 1996: 59-69; 1999: 93-98). Masingu piibliadaptatsioon on näide sellest, kuidas jumala karakter on sellise muutuse juba läbi teinud: temast on saanud isalik kaitsja. Kahtlemata leidub Masingu juttudes jumala viha ja karmikäelisuse märke, sest jumal karistab neid, kes on eksinud või temast ära pööranud (nt lood veeuputusest, Soodomast ja Gomorrast, Iisraeli rahva kiusamisest teel tõotatud maale jne), kuid nagu Bottigheimer (1999: 96) väidab, lahendasid protestandid, kelle hulka kuulusid nii Hübner kui ka Masing, jumala karakteri muutmise seeläbi, et nad eemaldasid piiblist episoodid, mis kutsusid esile jumala viha, ja sellepärast ei olnudki jumalat vaja kujutada 
vägivaldsena. Katoliiklastest piiblimugandajad hoidsid vabameelse seksuaalelu ja igat sorti vägivallategude kujutamisest kiivamalt kinni, kuid lahendasid karistuse probleemi puhastustulega, mis tabas patuseid pärast surma. Seetõttu ei pidanud ka nende jumal enam olema patuste nuhtleja, vaid sai muutuda pehmemaks.

Jumala iseloomu muutmine piiblilugudes on seotud VT ja UT omavahelise suhte muutumisega. Kuni XVIII sajandini moodustas religiooniõpetuse aluse VT, kuid alates valgustusajastust hakati rohkem tähelepanu pöörama UT-le, millest sai XIX sajandi jooksul kristlastele keskse tähendusega tekst. Seda tähendusmuutust näitab selgesti ka Masingu piiblimugandus: VT lugude 39 osa mahuvad tal ära 92 lehele, UT lugude 52 peatükki võtavad enda alla aga 237 lehekülge. Hübneril näiteks on mõlemad piibliloo osad veel tasakaalus. Lisaks suuremale mahule näitab UT tähtsust Masingul ka see, et Jeesus Kristus leiab tema VT lugudes sageli mainimist. Nii on juba mõnede lugude pealkirjad sõnastatud Jeesuse tuleku ootuses või on Jeesuse õpetussõnu ja UT kirjakohti põimitud VT lugude sisse (Masing 1819: 50).

Masingu piiblimuganduse neljanda tekstivaliku põhimõttena võib nimetada realismitaotlust ja imetabase ning mõistuspäraselt seletamatu minimeerimist. Masingu VT lugudes ei mainita näiteks, et inimesed elavad kuni 400aastaseks ja saavad veel saja-aastastena lapsi, UT lugudes on redutseeritud Jeesuse imetegude arvu. Christine Reentsi järgi on juba Hübneri piiblilugude UT osas evangeeliumides kujutatud 60 imeteost kajastamist leidnud vaid 11 (Reents 1991: 240), Masingul 12. Näeme, et selles küsimuses on Masing suhteliselt truult järginud saksa alusteksti. Realismitaotluseks sisu tasandil võib lugeda ka selle, et Masing on teksti mugandanud talupoeglikule lugejaskonnale vastuvõetavaks; ta on neid VT lugusid, kus on juttu põlluharijate või karjakasvatajate elust, eriti põhjalikult lugeja silme ette maalinud, andes muu hulgas soovitusi ikaldusaastate üleelamiseks (Masing 1819: 25). UT lugudes rõhutab ta eriliselt Jeesuse sündimist viletsatesse oludesse, mis ei takistanud tal saada maailma õnnistegijaks ja kogu ilma valitsejaks (Masing 1824: 16).

\section{Vormilis-stiililine mugandamine}

Piibli mugandamine eesti talupoeglikule lugejale vastuvõetavaks seostub teise suure küsimusteringiga, teksti vormistamise ja keelelis-stiililise kujundamise põhimõtetega. Siingi järgib Masing oma saksa eeskuju, kuid talitab ka omasoodu. UT lugudesse on ta Hübnerilt üle võtnud kolmekordse metoodilise lisa, seda küll tugevasti Eesti oludele kohandades. VT lugude puhul on ta piirdunud vaid juttudega, neile ta Hübneri moodi küsimusi, õpetusi ja värsse lisanud ei ole.

Eraldi tähelepanu väärib UT lugude järel olev metoodiline lisa, mille struktuur on laenatud Hübnerilt, kuid sisu mitte. Nagu Hübneril nii on ka Masingul kolmeosaline lisa põhitekstist tüpograafiliselt selgelt eristatud. Kõigepealt on nummerdatud „,[k]üssimised, mis järrelearwamist tahtvad”, mida on iga peatüki lõpus keskeltläbi 5-8, maksimaalselt 14. Küsimustele järgnevad samuti nummerdatud „õppetused”, mida on iga loo lõpus kaks kuni viis, ja kõige lõpus on taandreaga muust tekstist eraldatud pühakirjasalm, mille eesmärk on anda loole aforistlik tõlgendus või moraal. 
Kui Hübneri katehheetilisel meetodil põhinevad küsimused toetuvad ühemõtteliselt eelnevalt loetud tekstile ja on lastele jõukohased, kusjuures neile vastuse leidmist hõlbustavad tekstis olevate lausete ees asuvad numbrid, mis vastavad küsimuste järjekorranumbrile, siis Masingu küsimustele tuleb vastused lugejal endal tekstist üles leida. Masingu eelistatud sünteetiline meetod (vt Masing 1996a: 213) nõuab vastajalt kriitilist eneseanalüüsi ning eelteadmisi nii kristlusest kui ka Eesti ühiskonnast. Masing ise on oma lähenemist Rosenplänterile kommenteerinud nii: „loole järgnevates küsimustes sisaldub ajend ja kutse vaagida meie rahva praegusi moraalseid ja intellektuaalseid vajadusi, eelarvamusi, eksimusi, eriti aga suure hulga eesti hernhuutlaste väärkujutlusi oma separatistlikest lahkõpetustest ja teesidest” (Masing 1996a: 250).

Õpetused, mida Masing küsimuste järel pakub, on oluliselt rohkesõnalisemad kui tema eeskujul Hübneril, kuid nad võtavad kokku esitatud loo sõnumi, mis võis nii jutustuses endas kui ka küsimustes ähmaseks jääda. Christine Reents on kindlaks teinud, et Hübneri piiblilugude UT osa 156 õpetussõnast, mida on iga peatüki järel alati täpselt kolm, tegelevad kaks viiendikku vaga kodanliku elukorralduse ülistusega, üks viiendik jumalasõna ja õige usu propageerimisega ning vaid kümnendik teose põhiteema Jeesuse Kristuse õpetusega. Ülejäänud pakuvad kujutatud religioossete praktikate või juudi ajaloo selgitusi (Reents 1991: 248). Masingul on õpetussõnu UT lugude peatükkide järel kokku 162 ja peaaegu pooled neist tegelevad inimeste jumalakartlikkusele ja -kuulekusele manitsemisega või räägivad jumalikust ettehooldusest (75). Teine suur teema on Masingul kodanlikud voorused (nt omavahelise koostöö ülistamine, kiusatusele mitte järeleandmine, sallivus, sõnapidamine, viha taltsutamine jms) (61) ja kolmas Jeesuse Kristuse õpetus (23).

Mõnes üksikus õpetussõnas selgitab Masing juudi kombeid, kristlikke tähtpäevi (nt suvistepüha ehk nelipüha) vms. Otseseid pöördumisi noore lugeja poole UT lugude kolmekordsest lisaaparaadist leiab, kuid mitte üleliia palju (Masing 1824: 13, 74-75, 115, 125). Ühed tähelepanuväärsemad õpetussõnad toonases ajas puudutavad raamatulugemist, mida Masing soovitab teha hingamisepäeval üksi olles, kusjuures ta ei soovita lugeda mitte ainult jumalasõna ega Jeesuse õpetust, vaid ka neid raamatuid, „mis kui innimeste kirjad, sinno ja kõige targema rahwa õppetuseks kirjutud" (Masing 1824: 106). Võib arvata, et ta mõtles nende all iseenda ja kolleegide rahvavalgustuslikke töid.

Võrreldes sellega, et Hübneri õpetussõnades domineerib kodanlik kombeõpetus, tundub ligi 100 aastat hiljem tegutsenud Masingu rõhk jumalasõnale anakronistliku reliktina. Selle põhjusi tuleb küllap taas otsida tema võitlusest hernhuutluse vastu, sest nii küsimustes kui ka õpetustes võib leida mitmesugust kriitikat vennastekoguduse aadressil (Masing 1824: 216-217), keda ta nimetab vale õpetajateks (Masing 1824: 189) või evangeeliumi ja jumalasõna segajateks (Masing 1824: 226). Vennastekoguduse vastu suunatuks võib pidada ka neid õpetussõnu, milles Masing kuulutab, et Jeesuse armu- ja tõeõpetuse kõige õigemad rahvale vahendajad on need, kes on hoole ja armastusega seda ametit õppinud ning sooritanud mitmesuguseid eksameid ja katseid (Masing 1824: 226) ehk omandanud teoloogi kutse nagu ta ise. Vennaste vagatseva, müstilise ja usulisse fanatismi kalduva liikumise vastu asetas 
Masing valgustatud luterluse, mis tegi panuse inimese mõistusele ja „loomulikule" moraalile.

Hübneri lisaaparaadi kolmanda osa, värsivormis riimitud mõttetera, mida on lihtne lugeda ja kerge meelde jätta ning mis kordab veel kord üle teksti mõtte, on Masing asendanud piiblisententsiga, nagu näiteks: „Sirak 2, 6. Ussu Jummalat, siis tulleb ta sulle appi; sea ommad teed hästi, ja lota temma peale" (Masing 1824: 58). Selline asendus on mõistetav, sest luuletamine ei ole lihtne ja luule tõlkimine on veelgi keerulisem, kuid teksti üldisele iseloomule ei ole selline samm minu meelest kasuks tulnud - Masingu tekst mõjub monotoonse ja moraliseerivana.

Keeleliselt võib Masingu piiblilugusid pidada õnnestunuks. Esineb küll saksa keele poolt mõjutatud kirjameestele iseloomulikke grammatilisi vigu (nt vigased objektikäänded, $m a$ - ja $d a$-infinitiivi ebaõige kasutus, artikli ja tarbetute lisasõnadega liialdamine, kongruentsireegli eiramine jms), otsetõlkeid (sks nieder kommen 'maha tulema = sünnitama'), ortograafilist ja morfoloogilist ebaühtlust, pikki ning lohisevaid lauseid või õ-tähe ülemäärast kasutamist, mis Arnold Kase (1970: 125) järgi võib tuleneda ka idamurde mõjudest, kuid siiski on tegemist oma aja kohta hea eesti keelega. Oli ju Masing üks XIX sajandi alguse paremaid eesti keele oskajaid, kelle autoriteeti tunnustasid paljud kaasaegsed ja kellele usaldati tähtsate seaduste ja ametlike teadaannete tõlkimine ning pastorikandidaatide teadmiste, sealhulgas ka eesti keele hindamine.

Kui analüüsida Masingu tekste sellest aspektist, kas nad on pigem piibli keele lähedased või mitte, siis ühest hinnangut on siin raske anda. VT lood kasutavad kohati 1739. aasta piiblile lähedast väljendusviisi, UT lugudes on autor endale võtnud suuremaid vabadusi. Näiteks esitab ta Luuka evangeeliumi 10. peatükis suhteliselt napilt jutustatud lugusid heast samariitlasest ja Jeesusest Marta ja Maarja kojas tervelt kahes erinevas peatükis (UT lood 27. ja 28. ptk). Sealjuures alustab ta 28. peatükki nii: „Olleme seiesadik Õnnisteggijat niihästi Pühas kojas, kui rahwa hulga keskes näinud immeteggusid teggewad, õppetawad, ja kawwala kirjatundjate pahhad nõud tühjaks teggewad: läkki siis nüüd Petania, ühte allewisse, Laatsaruse majasse, kedda Jesus armastas; et temmast õppida, kuidas issikeskeses ellus sõbrust pidada, ja neile, keda armastame, head sowida ja head teha" (Masing 1824: 104). On näha Masingu püüdu lugejat kaasa haarata, talle sündmusi elavalt ja arusaadavalt esitada, mis toob paratamatult kaasa kaugenemise piibli keelest. Kuna mõlemas raamatus võib leida lugejapöördumisi, mõiste- ja kontekstiselgitusi (nt pidalitõbi, pagan, prohvet, Paal jt), millele lisanduvad sündmuste lühendamised, tihendamised, ümberpaigutamised, võib Masingu lähenemist pidada adapteerivaks, rõhuga kaasajastamisele ja kommenteerimisele.

Masingu VT ja UT lugusid võib žanrilises mõttes pidada piiblilugudeks, nagu Masing isegi on neid määratlenud, mitte lastepiibliks. Nad ei ole mõeldud väikestele lastele, vaid pigem noortele ja täiskasvanutele. Nad lähtuvad toonase Eesti talurahva eluolust (vrd siiski kodanliku (seksuaal)moraali propageerimine) ja autori võitlusest hernhuutlastega ning sobivad kasutamiseks kodus ja/või koolis (lugude valik, pikkus, sünteetilisel teadmiste omandamise meetodil põhinev lisaaparaat). Olles saksa varavalgustusest pärit piibliadaptatsiooni mugandus eesti keelde, kujutavad Masingu piiblilood omamoodi teise astme tõlgendust, mis kaugeneb nii sisult kui ka vormilt piiblist märkimis- 
väärselt. Veelgi enam - jumalasõna on siin asetatud pedagoogiliste eesmärkide teenistusse, mis oli iseloomulik saksa valgustusteoloogia ühele suunale neoloogiale, mida Masing õppis tundma Halle ülikoolis teoloogiat õppides (1783-1786), kus see oli toona juhtiv teoloogiline suund.

\section{Muud religioonipedagoogilised tööd}

Et Masing on oma religioonipedagoogilised tööd kavandanud ühtse tervikuna, väärib tähelepanu veel üks aimekirjanduslik teos, mida võib žanrimääratluselt pidada usuõpetuse käsiraamatuks. Kirjas Rosenplänterile 19. märtsist 1818 ütleb ta, et on „visandanud plaani piiblilugude, lühikese kooliraamatu [s.o „Täielise ABD-Ramatu” - A.M.] ja õige lühikese piiblisissejuhatuse tarvis” (Masing 1995: 226). Viimase all peab ta silmas „Täielist Ristiusso õppetust" (1825), mis annab süstemaatilise ülevaate piibli osadest, nende kirjapanemise ajast, keelest ja eesmärkidest. Näiteks selgitab seda, et VT esimesi raamatuid tuleb mõista kui Iisraeli rahva ajalugu jumala valitsemise all või et UT-d tuleks lugeda kui ristiusu tekkimise ja levimise (esimesed ristikogudused) ajalugu. Samuti tutvustab see raamat piibli eri osade kirjapanijaid, VT tarku mehi ja UT prohveteid ning apostleid ning toob paljude võõraste sõnade, nähtuste või käitumispraktikate selgitusi (nt epistel, ingel, vaim, lunastamine, sakrament jne), avab taustu ja pakub tõlgendusi. Ristiusu rituaale (nt õpetus pühast ristimisest ja pühast õhtusöömaajast jms) selgitatakse nende praktilisest tähendusest lähtuvalt. Sealjuures on Masingu keel lopsakas ja kujundirohke; jumala suurtest tegudest jutustamiseks kasutab ta sisendusjõulist mina-vaatepunkti, meieisapalve tähendust avades haarab ta lugeja kaasa meie-vormi abil. Masing põimib jutu sisse piiblitsitaate ja aktuaalseid seiku iseenda või ümberkaudsete elust, kuid siiski leidub raamatus ka kuiva didaktilisust ja manitsusi, mis selle populaarsusele (noorte lugejate hulgas) kindlasti kasuks ei tulnud.

Raamat ei ole otseselt mõeldud lastele, alapealkirja järgi on see kirjutatud „targema rahwa ja koolmeistrite kassuks”, kuid õpetused, mis on jagatud 13 peatükki, on minu hinnangul jõukohased eri vanuses lugejatele. Nad avardavad lugeja teadmisi kristlusest, tehes seda ladusas ja talurahvale harjumuspärases keeles. Et „õige teadmine” ristiusust religioosselt keerulisel ajal (s.t võitluses hernhuutlastega) kiiremini lugejateni jõuaks ja vajalike tõdede juurutamine liiga kaua aega ei võtaks, kui sellega alustada noore rahva hulgas, otsustas Masing mõned raamatu osad juba oma Marahwa Näddala-Lehes ära trükkida (vt Masing 1996b: 217-218). Need ilmusidki 1822. aasta sügisel, numbrites $43-46$.

\section{Ilmalikud lugemispalad õpikutes}

Masingu kõige tuntumad lastekirjanduslikud tekstid on kahtlemata kaheksa ilmalikku jutustust „ABD ehk Luggemise-Ramatus Lastele”, vähem tähelepanu on pälvinud lugemiku veerimisharjutusena esitatud ilmalik kombeõpetus. On arvatud, et Masing on lugemikutekstide koostamisel saanud eeskuju ja toetust XVIII sajandi saksa valgustajatelt (Krusten 1995: 38), täpsemaid nimesid siiski ei mainita. Kuna Masing eelistas tõlkimisele mugandamist ja 
teksti kohandamist vastuvõtjakultuuri oludele vastavaks, on tema võimalike mõjutajate väljaselgitamine keeruline, peaaegu võimatu. Need vähesed pilgud, mis ma olen saanud heita väga tekstimahukasse saksa valgustusajastu laste- ja noortekirjandusse, näitavad selle aabits-lugemiku teatud sarnasusi Christian Felix Weiße (1726-1804) ja Johann Peter Hundeikeri (1751-1836) töödega, kuigi kindlad tõendid selle kohta puuduvad, et Masing oleks nende autorite loomingut tundnud või kasutanud. Saksa lastekirjanduse rajajaks peetava Weiße aabits-lugemik „Neues A, B, C, Buch, nebst einigen kleinen Uebungen und Unterhaltungen für Kinder” (1773, „Uus A, B, C, raamat lühikeste harjutuste ja meelelahutuslike paladega lastele”), mis sai Saksamaal traditsioone loovaks eeskujuks paljudele järgnevatele (Brunken 1982: 833), võib oma struktuuriga olla mõjutanud ka Masingut. Üks tema aabitsajuttudest sarnaneb aga peaaegu äravahetamiseni autodidaktist koolinõuniku Hundeikeri aabitsa „Privatfibel oder einsilbige angenehme und nützliche Uebungen im Lesen und Denken für Buchstabirschüler aus gesitteten Ständen” (1791, „Koduaabits ehk tagasihoidlikud meeldivad ja kasulikud lugemis- ja mõtlemisharjutused lugemaõppijatele hästikasvatatud seisusest") värssloole.

Mõlemad aabits-lugemikud on mõeldud koduõppeks: Weißel kodanlase- ja Masingul taluperes ning nende ülesehitus on sarnane. Nad algavad põhjaliku eessõnaga, milles puudutatakse lugemaõppimis- ja keeleküsimusi, k.a tähestikku, silbitamis- ja hääldusharjutusi ning kirjavahemärke. Masing teeb veel juttu lastekasvatusest, Weiße mitte, tema keskendub rohkem saksa ja ladina keele võrdlusele. Sellele järgneb mõlemal kombeõpetus: Weißel 72, Masingul 35 sententsi ja vanasõna, mis on mõlemal viimases osas antud trükitähtedega, kuid kokkulugemise lihtsustamiseks kogu ulatuses häälduspiiridega. Kuigi paljud neist mõtteteradest kattuvad, ei saa kindlalt väita, et Masing on need Weißelt laenanud, sest kohati on tegu universaalsete ütlustega, mida võib leida paljudes toonastes saksa-, aga ka eestikeelsetes kooliraamatutes. Näiteks: „Laps, ol-le ab-biks om-ma is-sa-le tem-ma wan-na-usses”, „Är-ra ol-le nob-be om-ma ke-le-ga, ja är-ra ol-le laisk om-ma teg-gu-des” (Masing 1795: 17-18). Sarnane on kahes raamatus moraaliõpetuse ilmalik suunitlus, manitsusi jumalakartusele võib leida vaid mõnest üksikust sententsist. Weißel on osa mõtteteradest antud kaherealistes riimitud salmides, Masing piirdub proosaga. Edasi järgib kumbki õpik oma struktuuri: Masing jätkab religioossete tekstidega ja jõuab siis jutustuste juurde, Weiße pakub lugemiseks kohe jutustusi. Temal on neid kokku 38, Masingul 8 ja võib kindlalt väita, et neid ei ole meie autor laenanud Weißelt, sest viimase lugude tegevuspaigaks on linn või asula ning tegelasteks kodanluseseisusesse kuuluvad lapsed. Masingu jutustuste sündmustik leiab aset maal, talutares. Erinev on ka jutustuste tonaalsus - Masingul karm didaktika, Weißel pigem õpetamine positiivsete näidete abil, millest kumab juba läbi filantroopide lapsesõbralikum ja lapse vajadusi ning võimeid arvestav maailmavaade, mis sai Saksamaal valdavaks alates 1770. aastatest (vt Ewers 1998: 26-45).

Laadilt sarnanevad Masingu jutustused rohkem Hundeikeri aabits-lugemikus leiduvate tekstidega, mida võib žanrimääratluselt pidada hoiatuslugudeks, nn musta pedagoogika näideteks. Sellise nimetuse andis kasvatusmeetodile, milles eksimustele järgneb karm karistus või isegi surm, saksa publitsist Katharina Rutschky, kes uuris varasemate sajandite lastele ja lastest kirjutatut (Rutschky 1977). Iseloomulikuks näiteks Masingu mustast pedagoo- 
gikast on lugu pealkirjaga „Üllekohtsest warrast ei olle siggidust”, milles väike Tomas varastab naabripoisilt noa ja läheb siis teiste lastega kukerpalle tegema. Kui ta end mäest alla veeretab, tungib põues olnud nuga talle kõhtu.

Tugevaid paralleele võib täheldada Hundeikeri (1791: 47) värssjutustuse „So geht's, wenn man lügt” („Nõnda juhtub, kui valetada”) ja Masingu „Kes ükskord walletanud, sedda ei ussuta mitte ennam" vahel. See räägib vallatust poisist, kes tekitab asjatult hundipaanikat, ja kui metsaline ühel päeval tõesti platsis, siis ei tule külarahvas talle enam appi, sest arvatakse, et ta teeb jälle nalja. Kui Hundeikeri loos sööb hunt lapse ära, siis Masing, kes on olustikku veidi rohkem välja joonistanud, nimetanud lapse Peetriks ja teinud tast karjapoisi, piirdub sellega, et laseb metsalise saagiks langeda lammastel. Mõlemad autorid toovad loo lõpus muust tekstist kas taandrea (Masing) või punasega (Hundeiker) eristatud moraali, mis meie autori sõnastatuna kõlab nii: „Kui sa tahhat armas lapsoke! et teised ikka peawad uskma mis sa ütled; - siis räki iggal ajal mis tõsi on ...." (Masing 1795: 27).

Rohkem sarnasusi Hundeikeri ja Masingu aabits-lugemike tekstide võrdlus ei näidanud, kuigi mõlemad autorid kujutavad maalapse elu ja käsitlevad musta pedagoogika võtmes valgustusajastu lastekirjandusele tüüpilisi teemasid (loomade piinamise ja vägijookide pruukimise keeld, vanemate sõna kuulamise käsk jt). Võib-olla on Masing kasutanud teisi eeskujusid, võib-olla kompileeris ta oma lood mitme allika põhjal, kuid igatahes võib kindlalt väita, et tema lastejutud on kaasahaaravad ja puändiga ning neis võib juba märgata mõningast kunstipära (tegelaste algeline karakteriseerimine, metafoorika). Eesti lastekirjanduse ajaloos seisavad tema jutustused erilisel kohal, sest lapse psühholoogia hea tundmise, lühiduse ja keelelise lihtsuse tõttu olid nad ajas, kus domineeris raskepärane ja manitsev religioosne kirjasõna, ainulaadsed. Eriliseks muudab raamatukese ka tiitelillustratsioon, puulõige, mis väidetavalt pärineb Masingult endalt (Erm 1976: 138). See kujutab talutare, kus kaks last, poiss ja tüdruk, seisavad vanemate ja noorema õe-venna ees, kusjuures isa ees laual lebab paks raamat, tõenäoliselt piibel, ja poisil on käes paberilehed, küllap õppematerjalid.

Lausa kahju, et Masingu (1995: 94, 144) poolt heaks eesti keele tundjaks peetud Alutaguse praosti Peter Kochi (1757-1816) kriitika raamatu keele aadressil Masingu (laste)kirjanduslikku tegevust pikkadeks aastateks pidurdas ja teda teose müümata jäänud 300 eksemplari põletama ajendas (Anvelt 1979: 43), kogutiraaž ei ole kahjuks teada. Kui Rosenplänter, kes 1813. aasta teise numbri Beiträges (25) oli aabitsa keelt kiitnud, ühes kirjas Masingule ette pani raamatuke uuesti välja anda, siis arvas enesekriitiline autor, et muudatusi tuleb ette võtta rohkem kui ühes suhtes, et teha sellest elementaar-kooliraamat, mis sobiks paremini ostjate ootustele (Masing 1995: 109). Ühes teises kirjas nimetas ta oma aabits-lugemikku armetuks ja vastikuks räbalaks, keele häbiplekiks, mille nägemine talle veel aastaid hiljemgi hävitavalt mõjus ja hoiatusena silme ees seisis (Masing 1995: 280). Küllap oligi autori liigne enesekriitilisus põhjuseks, miks kordustrükist asja ei saanud, kuid seda tuleb küll öelda, et hilisemad õpikud, mis Masing välja andis, ei olnud sisult ega keelelt enam nii lastepärased kui tema esimene lastekirjanduslik üllitis. 


\section{Perioodikas ilmunud palad}

Lastele ja noortele sobilikku lugemist leiab ka Masingu rahvavalgustusliku sisuga ajalehest Marahwa Näddala-Leht. Kuigi selle põhiteemad on võitlus ebausu vastu, maarahva majandusliku olukorra parandamine läbi põlluharimis-, loomakasvatus- ja tervishoiunõuannete, kodumaa ja kaugemate piirkondade ajaloolis-geograafilis-etnograafiline tutvustamine, loodusnähtuste ja tehnikasaavutuste kirjeldamine jms, leidub esimeses aastakäigus ka mitmekesist ilukirjanduslikku materjali (sh lastele). Mõni lugu pöördub juba pealkirjas otsesõnu laste poole, nagu näiteks „Lapsed! piddage meles seda käsko, mis tõutusega antud” (MNL 1821, 26). See räägib vanemate austamise vajadusest ja hurjutab vanemaid laste liigse hellitamise eest.

Ajalehes ilmunud ilukirjanduslikest vormidest on lastele kindlasti kõige sobivamad lühikesed (värss)mõistatused, mida on kõikide väljaannete peale kokku üheksa ja mis on sageli seotud keelemängude või keele omandamisega: nt „Wõtta: kot, not, pot, rot / kui tahhad, weel peälegi: lot: / wõtta ärra, mis kõigil neil ees; / siis olen ma noor-, ehk wannagi mees" (MNL 1821, 11: 88). Õiged vastused annab ta tavaliselt järgmises või mõnes hilisemas lehenumbris (antud juhul: mehe nimi Ot).

Teine lastele huvipakkuv žanr on paraboolid ehk mõistulood, mis ei ole Masingu originaallooming, vaid mõjutatud kuulsate valmimeistrite töödest. Juba ajalehe esimeses numbris esitab Masing Aisopose algupäraga loo „Arm jõuab ennam kui hirm” (MNL 1821, 1: 6-8) päikese ja tuule jõukatsumisest kummal õnnestub kiiremini mantel talumehe seljast maha saada. Rahvusvaheliselt tuntud on ka lugu pealkirjaga „Jummal on kõik targaste teinud (Üks mõistejut)" (MNL 1821, 3: 20-22), mis räägib talumehest, kes sõitleb jumalat, sest see on tammepuule liiga väikesed viljad teinud, kõrvitsad oleks kohasemad. Kui tõuseb tuul ja puu alla puhkama heitnud meest tabab tõrudesadu, võtab ta oma sõnad tagasi, mõistes, et jumal on siiski kõik õigesti teinud. Eesti keelde jõudis see mõistujutt esmakordselt saksa valgustusajastu kirjaniku Johann Wilhelm Ludwig Gleimi värssloo kaudu Reinhold Johann Winkleri vahendusel 1808. aasta Gresseli „Eesti-ma Rahwa kalendris”. Masing tegi värsivormilisest valmist proosapala, lisas olustikulisi detaile ning õpetussõnu. Hiljem on seda mõistulugu oma lastejuttude kogumikes esitanud ka Karl Körber (1863: 19-20) ja Carl Eduard Malm (1874: 38-39), samuti proosaversioonis.

Kõige kuulsam Masingu mõistulugu, mis aabitsatekstide kõrval meie (laste)kirjanduse ajalugudes ja ühes antoloogiaski (vt Jaaksoo 1997: 11-13) esiletõstmist on leidnud, on „Päts” (MNL 1821, 3: 22-24; 4: 25-27). Kui üldiselt teatakse, et Masing on selles värssloos toetunud Christian Fürchtegott Gellerti eeskujule (Vinkel 1966: 136; Kaalep 2001: 688-689), kusjuures Ain Kaalep rõhutab vaid motiivilisi sarnasusi Gellerti „Tantsukaruga” ja peab Masingu teost algupäraseks, siis küllap ei olnud Masingule tundmatu ka teine saksa valgustusajastu kirjanduse samanimeline meistriteos Gotthold Ephraim Lessingilt. Lessingil mõistavad kodumetsa karud Pätsi hukka uhkuse, edevuse ja oma juurte reetmise pärast, sest tantsukaru on omaks võtnud võõrad kombed ja kuulutab neid nüüd kui ainuõigeid. Meie kirjanduslood on Masingu teost tõlgendanud kibestumisena tema rahvahariduslike püüdluste ebaõnnestumise pärast (vanameelsed murravad Pätsu kadedusest), kuid kas ei 
võiks me sellest Lessingi tekstiga sarnaselt välja lugeda ka idee kättemaksust oma rahva reetmise ja võõra ideoloogia (kristlus) omaksvõtu pärast? Tõsi, lapslugeja jaoks, olgu toona või praegu, ei ole arvatavasti kummalgi tõlgendusel tähtsust.

Kolmas tüüpiline valgustusajastu laste- ja noortekirjanduse žanr, mida Marahwa Näddala-Lehest võib leida, on näidislugu ehk eksempel. Siia alla mahub ennekõike jutustus Maddi Reinust (MNL 1821, 36, 37), vaeslapsena üles kasvanud töökast ja arukast noormehest, kes valib endale kaasa südame järgi, mitte teiste soovitusel. See jutt, täieliku pealkirjaga „Hea inimene teeb tõistele sedda head, mis Jummal temmale hea rahwa läbbi lasknud tehha. Maddi Rein", sobib lastele ja noortele seetõttu, et selles on kujutatud peategelase lapsepõlve ja noorusaega, mil ta eluks tarvilikke kogemusi omandab (nt aednikutööd mõisas). Tähelepanuväärseks ja lastele kindlasti huvipakkuvaks muutis teksti sellele lisatud oforditehnikas illustratsioon „Maddi Rein”, mis ilmus lehe vahel pagineerimata kleebisena (MNL 1996b: 71) ja on esimene eesti ajakirjanduses ilmunud illustratsioon (Erm 1976: 137). Tegemist on Masingu enda tööga, mis kujutab Reinu kätlemas mõisnikuga, kes teda elluastumisel abistas.

Masingu rahvavalgustusliku ja pedagoogilise angažeerituse juures on mõneti üllatav, et ta ei näita Reinu teadmishimulisena: „Ta [Rein $-A$. M.] ei käinud kõrtsis; ei sõitnud ka mitte koli vahet; et ütles ilma selle viimseta Jummala ees lootvad armu leida ja toetas julgeste ommas südames sellesinatse pühha Kirja sõnna peäle, mis ütleb: kõige rahwa seast on se Jummala melest armas, kes tedda kardab ja õigust teeb" (MNL 1821, 37: 290). Teisiti öeldes ei pea Rein koolitarkust oluliseks, peaasi on jumalakartlikkus ja ausus teiste vastu, mida saab õppida ka pühakirjast. Lugu lõpeb sellega, et täiskasvanud Rein otsustab oma perre võtta kaks orbu, kuigi tema pere on juba suur - naine on kohe-kohe viienda lapsega maha saamas.

Kui lugeda Masingu teisi ajalehes avaldatud arvamusavaldusi eesti talulaste koolitamise teemadel, siis ei pruugi tema mõtted seoses Reinu hariduspüüdluste eitamisega nii ootamatud tunduda. Nimelt võttis Masing 1825. aasta kevadel läbi mitme kuu jutuks talurahva koolihariduse teema, hurjutades lapsevanemaid, et need ei saadaks oma võsukesi kallitesse saksakeelsetesse koolidesse. Mitte sellepärast, et maarahva ärksamaid päid ähvardab seal saksastumise oht ja nad lähevad niimoodi oma rahvale kaduma, vaid sellepärast, et talupojale piisab sellest, et lapsed „mõistlikuks ja kõlblikuks innimesiks saaksid, kes omma seisuse kutsumises kõikipiddi kõhhased oleks ni hästi mõistmise kui ka kõige mu nõu polest” (MNL 1825, 11: 82). Masing justkui oma kujunemisloo unustanuna - hoiab kinni seisuslikust ühiskonnast, mida näeb jumala poolt seatuna, ega pea sotsiaalset tõusu hariduse kaudu võimalikuks. Ta toob hulgaliselt näiteid juhmidest talupoistest, kelle koolitamise peale vanemad üksnes raha raiskavad. Põhjusi, miks talupojale paremat kooliharidust vaja ei ole, nimetab ta mitmeid: saksa keele õppimine on raske, kooliharidus on kallis, talulapsel ei jätku kooliskäimiseks piisavalt kannatust ja püsivust, ebaõnnestunult koolitatud lapsest ei saa enam korralikku põllumeest või käsitöölist jne. Tema arvates saaksid vajalikku elementaartarkust talurahvale anda ka valla- ja kihelkonnakoolid (MNL 1825, 18: 137138). 


\section{Kokkuvõte}

Kui vaadata Masingu laste- ja noortekirjanduslikku loomingut tervikuna, siis võib väita, et tema kirjatööd olid mõeldud talurahvale elementaarhariduse andmiseks, leidku see siis aset kodustes tingimustes või alamastme haridusasutuses, küla-, valla- või kihelkonnakoolides. 1820. aastad, mil valmis enamik siinkäsitletud tekste, olid Masingu elus tema rahvapedagoogilise tegevuse kõrgaeg - ta võttis nii ajakirjanduses kui ka erakirjavahetuses aktiivselt sõna maarahva kooliolude parandamise küsimuses (vt Masing 1996b: 185, 204, 271-272; Anvelt 1979: 72-78), tegi plaane talurahvakooli õpetajate seminari asutamiseks (Masing 1995: 198, 258), koostas õppematerjale. Sealjuures ei piirdunud need üksnes usuõpetusega, vaid pakkusid ka praktilisi nõuandeid ja mõningast meelelahutust.

Oma õpperaamatutesse põimis Masing mitmekesist materjali, mis vaimulikes žanrites ulatub katekismuseosadest ja lastepalvetest kuni piiblilugude ja pühakirja ülevaatliku tutvustuseni, ilmalikes žanrites aga (moraliseerivatest) näidislugudest, paraboolidest ja (värss)mõistatustest kuni kombeõpetuseni. Mitte ühelgi teisel toonasel eestikeelsel autoril ei ole ette näidata nii sisukat ja keeleliselt rikast loomingut kui temal.

Masingu laste- ja noortetekstide žanriline, temaatiline ja vormiline rikkus tuleneb nende laenulisusest. Suur osa tema töödest tugineb arvatavasti saksa eeskujudele, millega ta puutus kokku Saksamaal õppides. Kuna ta harrastas mugandav-adapteerivat lähenemist ega andnud oma allikatest eksplitsiitselt teada, ei ole kõikide tema eeskujude väljaselgitamine lihtne. Kindlad teadmised on meil vaid neist teostest, mida ta oma kirjavahetuses Rosenplänteriga või ka saksakeelsetes raamatureklaamides on maininud (nt Hübner), või mida varasem uurimistöö on kindlaks teinud (nt Gleim, Gellert). Teised võimalikud eeskujud (nt Hundeiker, Weiße) on leitud juhuslike otsingute tulemusena. Kuid on veel terve rida tekste, mille laenulisus või algupärasus vajab kontrollimist.

Hinnates Masingu vahendajategevust, võib kõigepealt esile tõsta tema alustekstide kõrget taset. Ta on saksakeelsest (laste- ja noorte)kirjandusest eesti lugejale vahendanud teoseid, mida võib pidada klassikalisteks valgustuskirjanduse näideteks ja traditsioone loovateks nii saksa kultuuriruumis kui ka laiemalt. Samuti tuleb tunnustada naturaliseerivat lähenemist alustekstidele. Eestikeelne kirjandus oli XIX sajandi alguses veel välja kujunemata ja kui tõlkijad ei oleks sugugi arvestanud siinse lugeja sotsiokultuurilise taustaga, vaid oleks võõrad mõttemustrid ja keelekontruktsioonid mehhaaniliselt üle kandnud, oleks see võinud mõjuda meie kultuuriruumile hukatuslikult. Naturaliseeriv tõlkimine oli laialt levinud praktika kogu toonases Euroopas; Masingu võimaliku eeskuju Weiße tekstid olid näiteks prantsuse lastekirjanduse tõlkemugandused (Brunken 1982: 831), mõistulood aga enamasti Aisopose algupäraga. See tõi kaasa sarnaste motiivide ja žanrite laia leviku Eu- roopa rahvaste laste- ja noortekirjanduses. Tänu Masingu vahendustegevusele tutvus ka eestikeelne lugeja valgustusajastu ideedega ja sai osa euroopalikest mõttemallidest.

Masingut võib pidada üheks esimeseks eesti kultuuriloos, kes pööras täiskasvanute harimise kõrval palju tähelepanu ka lastele ja noortele. ${ }^{3}$ Kaks

\footnotetext{
${ }^{3}$ Omaette küsimus, millele siinne artikkel ei keskendunud, on Masingu tekstide jõud-
} 
illustratsiooni, mis kaunistavad tema kirjatöid, teevad temast ühtlasi eesti lastekirjanduse esimese illustraatori. Samas näitavad Masingu tekstid väga ilmekalt, milliste raskustega oli seotud lastekirjanduse kui kirjanduse alaliigi väljakujunemine eesti keeles. Autoril tuli oma esialgseid kavatsusi sageli korrigeerida, kuna selgus, et järeleaitamist ilmaasjades, eriti moraalses plaanis, vajab ka täiskasvanud talupoeg. Ei olnud aega oodata, kuni sirgub „õiget õpetust” saanud põlvkond, talurahva harimisega tuli alustada kohe ja võimalikult laiapõhjaliselt. Sellepärast ongi paljud tema teosed suunatud laiale kasutajaskonnale ja jäänud seni laste- ja noortekirjandusuurimuse huviorbiidist välja.

\section{Kirjandus}

A d a m, Gottfried, L a ch m a n n, Rainer (toim) 1999. Kinder- und Schulbibeln. Probleme ihrer Erforschung. Göttingen: Vandenhoeck \& Ruprecht.

Ad a m, Gottfried, L a chmann, Rainer, Schindler, Regine 2003. Das Alte Testament in Kinderbibeln. Eine didaktische Herausforderung in Vergangenheit und Gegenwart. Zürich: Theologischer Verlag.

Andresen, Lembit 2002. Eesti rahvakooli ja pedagoogika ajalugu III. Koolireformid ja venestamine (1803-1918). Tallinn: Avita.

An n u s, Endel 2000. Eesti kalendrikirjandus 1720-1900. Tallinn: Teaduste Akadeemia Kirjastus.

Anvelt, Leo 1979. O. W. Masing ja kaasaegsed. Lisandusi nende tundmiseks. Tallinn: Eesti Raamat.

Beiträge zur genauern Kenntniss der ehstnischen Sprache 1813-1832. Toim J. H. Rosenplänter. Pernau: Marquardt.

B i c h l e r, Albert 2001. Kindergebet. - Kinder- und Jugendliteratur. Ein Lexikon. Autoren, Illustratoren, Verlage, Begriffe. Loseblätter seit 1995. Toim A. Baumgärtner, K. F. Clemens. Meitingen: Corian-Verlag, lk 1-17.

B o t t ig h e i m e r, Ruth B. 1991. Religion for the Young in Bible Story Collections. - Fabula. Zeitschrift für Erzählforschung (32), nr 1-3, lk 19-32.

B o t tig h e i m e r, Ruth B. 1996. The Bible for Children. From the Age of Gutenberg to the Present. New Haven-London: Yale University Press.

B o t tig h e i m e r, Ruth B. 1999. Gott in Kinderbibeln. Der veränderliche Charakter des Gottes. - G. Adam, R. Lachmann (toim), Kinder- und Schulbibeln. Probleme ihrer Erforschung. Göttingen: Vandenhoeck \& Ruprecht, lk 90-102.

B r u n k e n, Otto 1982. Christian Felix Weiße (1726-1804): Neues, A, B, C, Buch, nebst einigen kleinen Uebungen und Unterhaltungen für Kinder. Frankfurt und Leipzig 1773. - T. Brüggemann, H.-H. Ewers (toim), Handbuch zur Kinder- und Jugendliteratur von 1750 bis 1800. Stuttgart: Metzler, lk 830-834.

E r m, Voldemar 1976. Otto Wilhelm Masing illustraatorina. - Töid kunstiteaduse ja -kriitika alalt 1. Artiklite kogumik. Tallinn: Kunst, lk 133-141.

E w e r s, Hans-Heino 1998 [1980]. Kinder- und Jugendliteratur der Aufklärung. Eine Textsammlung. Reclam Universal-Bibliothek Nr. 9992. Stuttgart: Reclam. He n n ing, Carl Matthias 1821. Kaks kord viiskümmend kaks Piibli-luggemist

mine reaalsete lugejateni. On teada, et tema piiblilood juurdusid külakoolides pietistidest pastorite ja köstrite vastuseisu tõttu halvasti (vt nt Masing 1996b: 90), ja tuntud on ka autori kaebused oma ajalehe kehva leviku üle. 
wannast ja uest testamendist, mis meie ma rahwa laste öppetusseks Saksa kelest Ma kele üllespannud Karel Maddis Henning. Tallinn: Gressel.

Hundeiker, Johann Peter 1791. Privatfibel oder einsilbige angenehme und nützliche Uebungen im Lesen und Denken für Buchstabirschüler aus gesitteten Ständen. Braunschweig. Schulbuchhandlung. - http://rzbl04.biblio.etc.tubs.de:8080/docportal/receive/DocPortal_document_00028956 (20. X 2011).

$\mathrm{H} \ddot{\mathrm{u}} \mathrm{b}$ n e r, Johann 1986. Zweymal zwey und funffzig Auserlesene Biblische Historien Aus dem Alten und Neuen Testamente. Der Jugend zum Besten abgefasset. Mit Vorwort, Einführung und theologie- und illustrationsgeschichtlichem Anhang. Toim R. Lachmann, C. Reents. Erste illustrierte Ausgabe Letzter Hand, Leipzig 1731. Hildesheim-Zürich-New York: Olms.

J a a k s o o, Andres (koost) 1997. Eesti lastekirjanduse antoloogia. II kd. Kuule, Kutsik, kuhu lähed? Tallinn: Steamark.

J ä r v, Ants 1989. Eesti lastekirjandus. Kujunemine ja areng kuni a. 1917. Tartu: TRÜ trükikoda.

K a a l e p, Ain 2001. Tantsukaru. Christian Fürchtegott Gellert. Tlk A. Kaalep. Akadeemia, nr 4, lk 687-689.

K a s k, Arnold 1970. Eesti kirjakeele ajaloost I. Tartu: Taru Riiklik Ülikool.

Kru st e n, Reet 1995. Eesti lastekirjandus. Tartu: Elmatar.

K ö r b e r, Karl 1863. Pähkle ramat. Tartu: Laakmann.

L a u l, Endel (toim) 1989. Eesti kooli ajalugu neljas köites. Kaugemast minevikust tänapäevani. Peatoim Ferdinand Eisen. 1. kd. 13. sajandist 1860. aastateni. Tallinn: Valgus.

M a l m, Carl Eduard 1874. Laulud ja Loud. Üks kooli-lugemise-raamat. Tallinn: Kluge.

M a s in g, Otto Wilhelm 1795. ABD ehk Luggemise-Ramat Lastele kes tahawad luggema õppida. Tartu: Grenzius.

M a sing, Otto-Wilhelm 1818. Pühhapäwa Wahhe-luggemissed. Essimenne jaggu mis Otto Wilhelm Masing kirjutand ja wäljaandnud. Tartu: Schünmann.

M a s i n g, Otto Wilhelm 1819. Wanna-seädusse-aja sündinud asjad, mis WannasTestamendist kokkokirjutand ja nore rahwa õppetusseks trükki pannud Otto Willem Masing. Tartu: Schünmann.

M a sing, Otto Wilhelm 1821a. Luggemisse lehhed mis Otto Willem Masing wäljaandnud. Tartu: Schünmann.

M a sing, Otto Wilhelm 1821b. Õppetus kuida neid luggemise lehti kassuga prukida, mis Otto Willem Masing wäljaandnud. Tartu: Schünmann.

M a s in g, Otto Wilhelm 1823a. Arwamise-ramat. 1 Tük mis Otto Willem Masing koolmeistrite ja kolilaste kassuks wäljaandnud. Tartu: Schünmann.

M a s ing, Otto Wilhelm 1823b. Täieline ABD-Ramat, kust makele luggemist õiete õppida. Tartu: Schünmann.

M a s in g, Otto Wilhelm 1824. Wiiskümmend kaks luggemist Uest-Testamendist wäljawallitsetud, kuhhu küssimisi, mis mõtlemist tahtvad, häid õppetusi, ja pühha kirja salmisid jurepandud, mis Otto Willem Masing, nore rahwa ja kolilaste heaks wäljaandnud. Pärnu: Markwart.

M a s in g, Otto Wilhlem 1825. Täieline Ristiusso õppetus mis targema rahwa ja koolmeistrite kassuks wäljaandnud Otto Willem Masing. Pärnu: Markwart.

Masing 1995 = Otto Wilhelm Masingu kirjad Johann Heinrich Rosenplänterile 1814-1832. Esimene köide 1814-1818. Tartu: Eesti Kirjandusmuuseum. 
Masing 1996a = Otto Wilhelm Masingu kirjad Johann Heinrich Rosenplänterile 1814-1832. Teine köide 1818-1820. Tartu: Eesti Kirjandusmuuseum.

Masing $1996 \mathrm{~b}=$ Otto Wilhelm Masingu kirjad Johann Heinrich Rosenplänterile 1814-1832. Kolmas köide 1821-1823. Tartu: Eesti Kirjandusmuuseum.

MNL = Marahwa Näddala-Leht mis Otto Willem Masing 1821-1825 wäljaandnud. Tartu, Pärnu. - DEA = Digiteeritud eesti ajalehed. http://dea.nlib.ee /

Piibel. - Eesti Piibliseltsi elektrooniline väljaanne. www.piibel.net

Põ l d m ä e, Rudolf 2011. Vennastekoguduse kirjandus. Tartu: Ilmamaa.

R e e n ts, Christine 1984. Die Bibel als Schul- und Hausbuch für Kinder. Werkanalyse und Wirkungsgeschichte einer frühen Schul- und Kinderbibel im evangelischen Raum: Johann Hübner, Zweymal zwey und funffzig Auserlesene Biblische Historien, der Jugend zum Besten abgefasset... Leipzig 1714 bis Leipzig 1874 und Schwelm 1902. Arbeiten zur Religionspädagogik 2. Göttingen: Vandenhoeck \& Ruprecht.

R e e n t s, Christine 1991. Johann Hübner (1668-1731): Zweymal zwey und funffzig Auserlesene Biblische Historien aus dem Alten und Neuen Testamente. Leipzig 1731 (Bibl. Nr. 452). - T. Brüggemann, O. Brunken (toim), Handbuch zur Kinder- und Jugendliteratur von 1570-1750. Stuttgart: Metzler, lk 231259.

R o s e n b e r g e r, Gertraud 1997. Das große Buch für kleine Leute. Kriterien und Beurteilung ausgewählter Kinderbibeln. Religionspädagogische Perspektiven. Kd 28. Essen: Die Blaue Eule.

Rutschky, Katharina (toim) 1977. Schwarze Pädagogik. Quellen zur Naturgeschichte der bürgerlichen Erziehung. Berlin: Ullstein.

Vi n k e l, Aarne 1966. Eesti rahvaraamat. Ülevaade XVIII ja XIX sajandi lugemisvarast. Tallinn: Eesti Raamat.

W e i ß e, Christian Felix 1777. Neues A, B, C, Buch nebst einigen Uebungen und Unterhaltungen für Kinder. Leipzig: Crusius.

\section{Otto Wilhelm Masing als aufklärerischer Kinder- und Jugendautor}

Stichworte: Geschichte der estnischen Kinder- und Jugendliteratur, Gattungen der aufklärerischen Kinder- und Jugendliteratur, deutsch-estnische Literaturbeziehungen

Otto Wilhelm Masing (1763-1832) gilt in der estnischen Kulturgeschichte als Aufklärer par excellence. Auch in der Geschichte der estnischen Kinderliteratur wurden seine Verdienste gewürdigt, weil er im Jahre 1795 ein ABC-Buch mit weltlichen Lesetexten veröffentlichte, das einzigartig und seiner Zeit voraus war. Masing hat noch weitere ABC-Bücher, didaktische Erzählungen und religiöse Texte für Jugendliche verfasst, die allerdings bisher noch nicht untersucht sind. Der vorliegende Artikel nimmt alle seine Werke, die an Kinder und Jugendliche gerichtet sind, unter genauere Betrachtung und analysiert ihre inhaltlichen und formalen Eigenschaften sowie sucht ihre möglichen Vorbilder.

Den größeren Teil seines Kinder- und Jugendwerkes bilden religiöse Texte, zwei Historienbibeln (1819, 1824), die Adaptationen des traditionenbildenden Werkes von Johann Hübner „Zweymal zwey und funffzig Auserlesene Biblische Historien Aus dem Alten und Neuen Testamente" (1714) sind, und ein religiöses 
Haus- und Handbuch (1825). Darüber hinaus hat Masing in seinen ABC-Büchern Kindergebete und biblische Sprüche gebracht, die zu den wichtigen Gattungen der aufklärerischen religiösen Kinder- und Jugendliteratur gehören. Die zweite Gruppe seiner Kinder- und Jugendtexte bilden acht didaktische Erzählungen und Sittenlehren aus dem ABC-Buch des Jahres 1795 sowie Parabeln, Beispielgeschichten und (Vers)Rätsel aus der von ihm selbst herausgegebenen „Wochenzeitung des Landvolkes" (1821-1823, 1825). Die Untersuchung der weltlichen Texte von Masing ergab, daß seine möglichen Vorbilder Christian Felix Weiße, Johann Peter Hundeiker, Johann Wilhelm Ludwig Gleim und Christian Fürchtegott Gellert sind - hervorragende Vertreter der deutschen aufklärerischen Kinder- und Jugendliteratur.

Masing ist seinen deutschen Vorbildern nicht sklavisch gefolgt, sondern hat die Texte den Bedürfnissen und dem Bildungsstand des bäuerlichen Lesers angepasst, was bedeutet, dass er einige ursprünglich kinder- und jugendliterarische Texte in doppeladressierte Werke umgewandelt hat, weil in Belangen, die über den bäuerlichen Alltag hinausgingen, bedurften nicht nur estnische Kinder und Jugendliche Nachhilfe, sondern auch Erwachsene. Dennoch gehört er zu den hervorragendsten und vielseitigsten Autoren der estnischen Kinder- und Jugendliteratur der Aufklärungszeit.

Ave Mattheus (geb. 1971), MA, Universität Tallinn, Institut für Estnische Sprache und Kultur, Lektorin für vergleichende Literaturwissenschaft,

ave.mattheus@tlu.ee 